\title{
Facial asymmetry in crying newborn
}

\author{
Miguel Magalhães, ${ }^{1}$ Diogo Costa, ${ }^{1}$ Angela Brites, ${ }^{1}$ Joana Teixeira ${ }^{2}$
}

${ }^{1}$ USF Barão de Nova Sintra, Porto, Portugal

${ }^{2}$ Hospital de Braga, Braga, Portugal

\section{Correspondence to} Dr Miguel Magalhães, miguelsm.86.mgf@gmail.com

Accepted 22 June 2015
CrossMark

To cite: Magalhães $M$, Costa D, Brites A, et al. BMJ Case Rep Published online: [please include Day Month Year] doi:10.1136/bcr-2015211212

\section{DESCRIPTION}

A 6-day-old newborn girl from an unremarkable pregnancy and vaginal delivery was observed for the first time by her primary care physician presenting facial asymmetry when crying. Physical and neurological examination showed facial asymmetry noted only on crying, with a drooping of the right corner of the mouth (figure 1). The eyelid closure, nasolabial fold depths, forehead elevation and tearing, were symmetric and normal. The facial asymmetry disappeared after the crying stopped (figure 2) and, according to the mother, this was happening since birth.

Asymmetric crying facies (ACF) is characterised by lower lip asymmetry in neonates only during crying. ${ }^{1}$ ACF has an incidence of 1:160 live births. ${ }^{1}$ It can result from a developmental abnormality caused by absence (agenesis) or incomplete development (hypoplasia) of the depressor muscle of the angle of the mouth or of the depressor muscle of the lower lip; likewise, it can result from a traumatic compression of the facial nerve in utero or during labour. ${ }^{12}$

ACF, considered a minor anomaly, however, causes severe parental distress. If misdiagnosed it

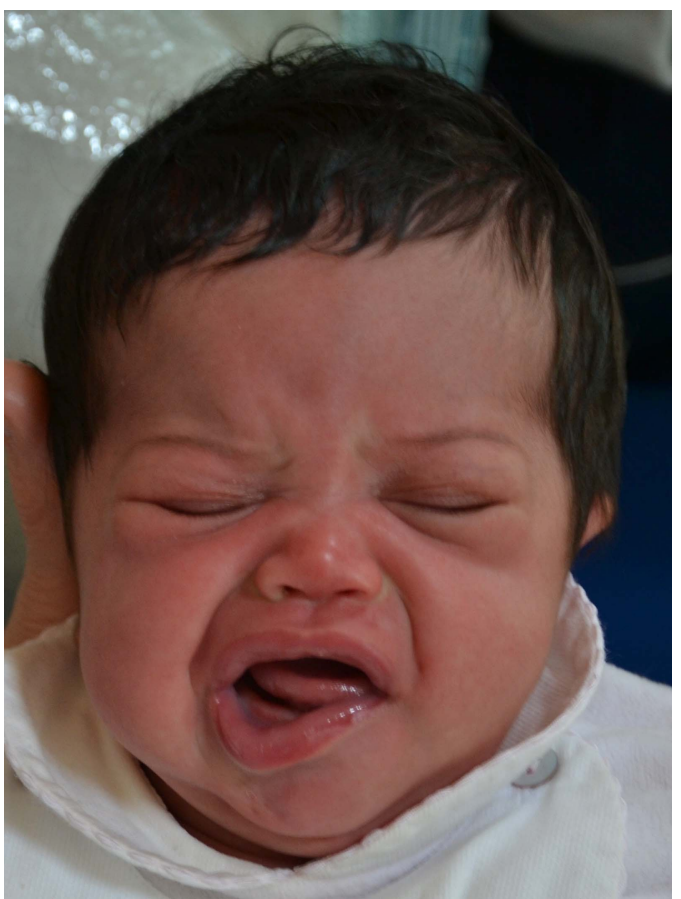

Figure 1 When crying, the right lower lip is pulled downward. The left affected side maintains its position.

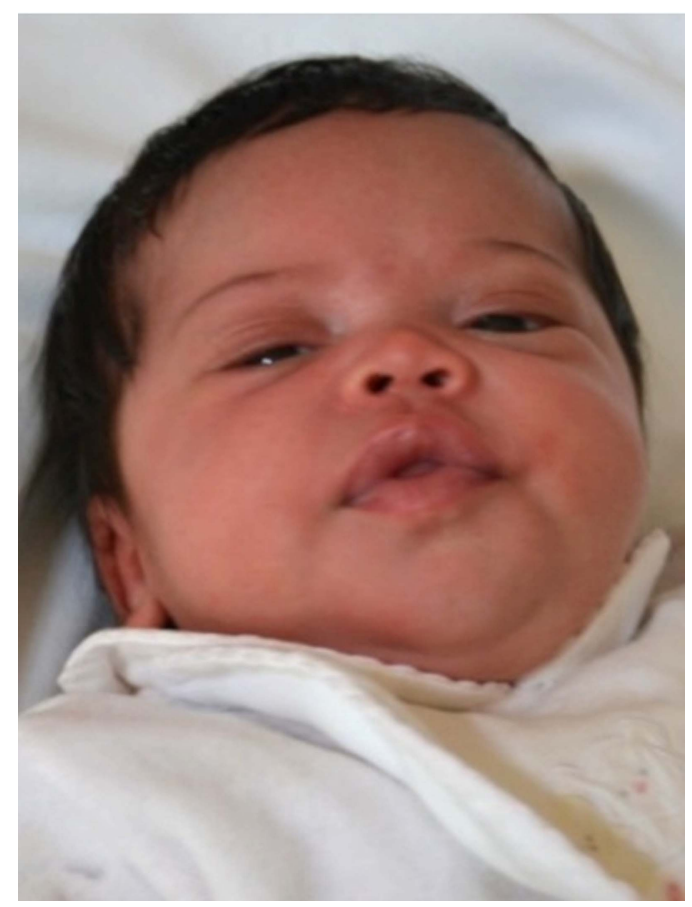

Figure 2 At rest, the face appears symmetric.

can lead to unnecessary work up and even inappropriate treatments. ${ }^{2}{ }^{3}$ ACF should be differentiated from other facial asymmetries, namely facial palsy, and the differential diagnosis is purely clinical. ${ }^{1}$

In the case reported, since no complications were described during delivery, congenital ACF was suspected. It has been associated with other congenital abnormalities such as of cardiovascular, genitourinary, respiratory and musculoskeletal origin. ${ }^{3}$ Our patient had no suspicion of coexisting anomalies and was therefore kept under clinical surveillance.

\section{Learning points}

Asymmetric crying facies (ACF) is a minor facial anomaly that consists of asymmetry during crying and can be differentiated from true facial palsy solely on a clinical basis.

- The management of ACF depends on the primary cause, namely trauma or muscular hypoplasia/agenesis, where associated congenital abnormalities are possible. 
Competing interests None declared.

Patient consent Obtained.

Provenance and peer review Not commissioned; externally peer reviewed.

\section{REFERENCES}

1 Shapira M, Borochowitz ZU. Asymmetric crying facies. Neoreviews 2009;10:e502-9.

2 Batra D. Management of facial nerve palsy in newborn period. Nottingham Neonatal Serv Clin Guidel 2013;F16:1-5.

3 Caksen $\mathrm{H}$, Odabaş $\mathrm{D}$, Tuncer $\mathrm{O}$, et al. A review of 35 cases of asymmetric crying facies. Genet Couns 2004;15:159-65.

Copyright 2015 BMJ Publishing Group. All rights reserved. For permission to reuse any of this content visit http://group.bmj.com/group/rights-licensing/permissions.

BMJ Case Report Fellows may re-use this article for personal use and teaching without any further permission.

Become a Fellow of BMJ Case Reports today and you can:

- Submit as many cases as you like

- Enjoy fast sympathetic peer review and rapid publication of accepted articles

- Access all the published articles

- Re-use any of the published material for personal use and teaching without further permission

For information on Institutional Fellowships contact consortiasales@bmjgroup.com

Visit casereports.bmj.com for more articles like this and to become a Fellow 